\title{
PERANCANGAN MATERI KAMPANYE DISABILITAS UNTUK KELOMPOK DIFABEL DI KLATEN, JAWA TENGAH
}

\author{
Yulianto Hadiprawiro, Febrianto Saptodewo, Deni Setiawan \\ Program Studi Desain Komunikasi Visual \\ Fakultas Bahasa dan Seni, Universitas Indraprasta PGRI
}

\begin{abstract}
Abstrak. Ketidak sempurnaan bentuk tubuh manusia bukan menjadi suatu penghalang untuk membantu membentuk brand kelompok difabel Klaten. Namun mereka memutuhkan kesetaraan dan kebutuhan pelayanan publik dengan non-difabel. Konsep dasar perancangan berangkat dari tema "difabel unggul klaten inklusi" diplikasikan pada desain kaos dan x bannner, dan medsos, instagram. Proses perancangan yang dilakukan oleh Universitas Indraprasta PGRI adalah menawarkan desain yang digunakan untuk membantu kelompok Difabel Klaten dalam membentuk image dirinya terhadap masyarakat Klaten.
\end{abstract}

Kata Kunci: difabel, brand, Klaten, kampanye

\begin{abstract}
Imperfections in the shape of the human body are not a barrier to help form the Klaten disability group brand. But they need equality and the need for public services with non-disabled people. Difabel Klaten requires campaign branding in the framework of International Disability Day 2019. The basic concept of design departs from the theme of "superior diffable Klaten inclusion" applied to the design of t-shirts, $x$ banners, and social media such as Instagram. The design process carried out by the Indraprasta University PGRI team is offering a design that is used to help the Klaten Difabel group in shaping their image of the Klaten community.
\end{abstract}

Keywords: disabled, brand, Klaten, campaign

Correspondence author: Yulianto Hadiprawiro, antoberlinsma@gmail.com, Depok,Indonesia

\section{Pendahuluan}

Penyandang Disabilitas atau lebih banyak dikenalkan dengan nama Difabel dari kepanjangan Different Ability People, memiliki daya juang dari sebelum adanya UndangUndang (UU) nomor 4 tahun 1997 tentang Penyandang Cacat untuk memenuhi kebutuhan haknya akan pelayanan publik. Pelbagai langkah advokasi terus menerus dilakukan agar terciptanya kesetaraan dalam menjalani kehidupan antara difabel dengan non-difabel. Dalam 
keberjalanan advokasi, penyandang difabel membutuhkan branding untuk mempertahankan eksistensinya.

Permasalahan yang dihadapi oleh penyandang disabilitas tidak hanya pada pendidikan dasar hingga pendidikan menengah atas, tetapi juga pasca pendidikan menengah atas. Secara formal, akses pendidikan nondiskriminatif bagi penyandang disabilitas sudah dijamin oleh Undang-Undang Nomor 20 Tahun 2003 tentang Sistem Pendidikan Nasional dan Peraturan Menteri Pendidikan Nasional Nomor 70 Tahun 2009 tentang Pendidikan Inklusi (Rizky 52-59). Selain itu kepada masyarakat disabilitas telah ada beberapa usaha yang dilakukan. Untuk meningkatkan kesejahteraan ekonomi penyandang disabilitas, pemerintah dan pemangku kepentingan perlu mengembangkan strategi program pendampingan masyarakat agar tepat sasaran dan bermanfaat bagi masyarakat penyandang disabilitas. Salah satu program pengembangan ekonomi masyarakat yang bisa dilakukan adalah melalui pendekatan pengembangan digital (Pramudyanto et al.). Selain itu, Istilah lain yang kemudian mengemuka adalah Penyandang Disabilitas. Istilah ini muncul melalui lokakarya yang diselenggarakan Kementerian Sosial RI tanggal 31 Maret 2010. Istilah ini disepakati untuk menggantikan kata penyandang cacat. Kesepakatan untuk menggunakan istilah penyandang disabilitas didasarkan pada 15 alasan, yaitu: (1) Mendeskripsikan secara jelas subjek yang dimaksud dengan istilah, (2) Mendeskripsikan fakta nyata, (3) Tidak mengandung unsur negatif, (4) Menumbuhkan semangat pemberdayaan, (5) Memberikan inspirasi hal-hal positif, (6) Istilah belum digunakan oleh pihak lain mencegah kerancuan istilah, (7) Memperhatikan ragam pemakai dan ragam pemakaian, (8) Dapat diserap dan dimengerti oleh pelbagai kalangan secara tepat, (9) Bersifat representatif untuk kepentingan reatifikasi konvensi, (10) Mempertimbangkan keselarasan istilah dengan istilah internasional, (11) Memperhatikan prespektif linguistic, (12) Sesuai prinsip-prinsip Hak Azasi Manusia, (13) Bukan istilah yang mengandung kekerasan bahasa atau mengandung unsur pemanis, (14) Menggambarkan adanya hak perlakuan khusus, (15) Memperhatikan dinamika perkembangan masyarakat (Probosiwi).

Kepercayaan merek atau brand bila didefinisikan sebagai harapan keandalan dan niat dari suatu merek, oleh karena itu kepercayaan merek mencerminkan dua hal: keandalan merek dan intensitas merek (Ballester dalam Foster). Chaudhuri \& Holbrook (dalam Foster) juga menyatakan bahwa kepercayaan merek sebagai kemampuan konsumen untuk bergantung pada kemampuan merek untuk melakukan fungsi-fungsi yang diekspresikannya.

Menurut McNally \& Speak (dalam Fauziah et al.) disebutkan bahwa personal brand merupakan merek pribadi yang melekat pada diri seseorang. Personal brand akan membuat orang lain memandang bahwa seseorang berbeda dan unik. Orang mungkin akan lupa dengan wajah, tetapi merek pribadi akan selalu diingat orang lain. Konsistensi merupakan syarat sebuah personal brand yang kuat. Hal-hal yang tidak konsisten akan melemahkan personal brand yang ada, dimana pada akhirnya akan menghilangkan kepercayaan serta ingatan orang lain terhadap seseorang yang tidak memiliki merek pribadi dan keunikan. Dalam keberjalanan advokasi, penyandang difabel membutuhkan branding untuk mempertahankan eksistensinya. Kebutuhan branding tidak hanya dibutuhkan oleh perusahaan besar yang berorientasi profit seperti Danone, Coca-Cola, namun juga dibutuhkan oleh organisasi-organisasi non-profit seperti kelompok difabel. Branding is a disciplined process used to build awareness and extend customer loyalty. It requires a mandate from the top and readiness to invest in the future (Wheeler 6). Branding merupakan serangkaian proses yang diciptakan untuk meninggalkan jejak di pikiran konsumen dan menjadikan konsumen loyal terhadap produk atau jasa tersebut. Sementara, Venus (dalam Untarni and Rahman) menyampaikan penyelenggara kampanye 
umumnya bukanlah individu melainkan lembaga atau organisasi. Lembaga tersebut dapat berasal dari lingkungan pemerintah, kalangan swasta atau lembaga swadaya masyarakat.

Kampanye sosial menurut Rogers and Storey (dalam Indrawan et al.) kampanye adalah gerakan (tindakan) serentak (melawan atau mengadakan aksi). Sedangkan sosial adalah semua hal yang berkenaan dengan masyarakat. Kampanye sosial didefinisikan sebagai serangkaian tindakan komunikasi yang terencana dengan tujuan untuk menciptakan efek tertentu pada sejumlah besar masyarakat yang dilakukan secara berkelanjutan pada kurun waktu tertentu"

Tidak banyak kelompok atau organisasi difabel di tingkat apapun yang menggunakan materi kampanye secara konsisten sebagai sebuah branding yang konsisten. Hal ini terjadi juga di Klaten yang notabene bergerak dari difabel akar rumput. Mereka masih belum menggunakan kampanye yang terfokus menggunakan warna yang senada. Apalagi ada acara Hari Disabilitas Internasional yang diperingati setiap 3 Desember 2019. Belum ada perencanaan bagaimana bentuk visual sebagai branding yang akan digunakan dalam acara tersebut. Pihak mitra yang bekerjasama dalam abdimas kali ini adalah Forum Komunikasi Masyarakat Peduli Difabel (FKMPD) dan Perkumpulan Penyandang Disabilitas Klaten (PPDK) di Klaten, Jawa Tengah.

Kampanye ini bagi kelompok disabilitas merupakan bagian dari usaha pemberdayaan. Suharto (dalam Rodiah 77-78) mengatakan bahwa Kelompok disabilitas merupakan kelompok yang perlu diberdayakan. Pemberdayaan merupakan suatu usaha yang dilakukan untuk memperbaiki kehidupan melalui penguatan kapasitas diri. Terdapat tiga indikator keberdayaan menurut Parsons, antara lain (1) Sebuah proses pembangunan yang bermula dari pertumbuhan individual yang kemudian berkmbang menjadi sebuah perubahan sosial tang lebih besar. (2) Sebuah keadaan psikologis yang ditandai oleh rasa percaya diri, berguna dan mampu mengandalkan diri sendiri dan orang lain. (3) Pembebasan yang dihasilkan dari sebuah gerakan sosial, yang dimulai dari pendidikan dan politisasi orang-orang lemah dan kemudian melibatkan upaya kolektif dari orang lemah tersebut untuk memperolah kekuasaan dan mengubah struktur-struktur yang masih menekan.

\section{Metode}

Dengan melihat permasalahan yang ada, solusi yang akan diberikan dari kegiatan perancangan ini kami membuat perancangan kampanye, agar merek untuk advokasi kelompok difabel di Klaten tetap terjaga sesuai dengan isu yang dibawa dalam Hari Disabilitas Internasional yang jatuh pada tanggal 1 bulan Desember tahun 2019. Dari hasil observasi awal yang dilakukan tim pengusul sebelum dilaksanakan tindakan pada proses perancangan materi kampanye, kami melihat bahwa belum ada perancangan materi kampanye untuk hari besar yang mereka rayakan setiap tahunnya, yaitu pada 3 Desember. Melihat hal tersebut, sebagai langkah advokasi untuk memperjuangkan hak-hak difabel di Hari Difabel Internasional, maka perlu adanya perancangan materi kampanye untuk dapat menjaga konsistensi brand yang ada di FKMPD dan PPDK Klaten. 


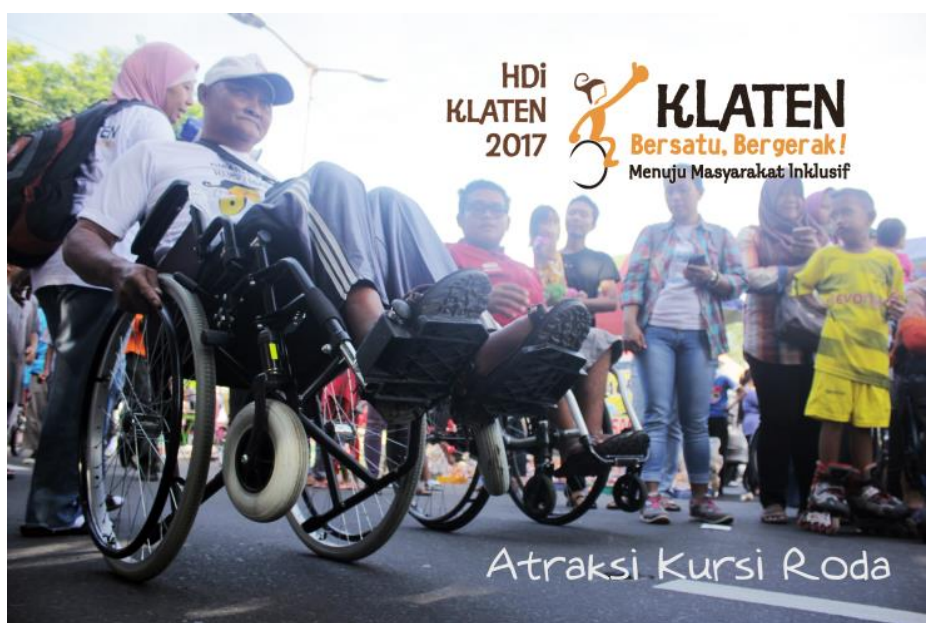

Gambar 1 Tampilan aplikasi logo dan maskot untuk acara Difabel Klaten dalam HDI Klaten 2017. Sumber: Dokumen Mitra, 2017

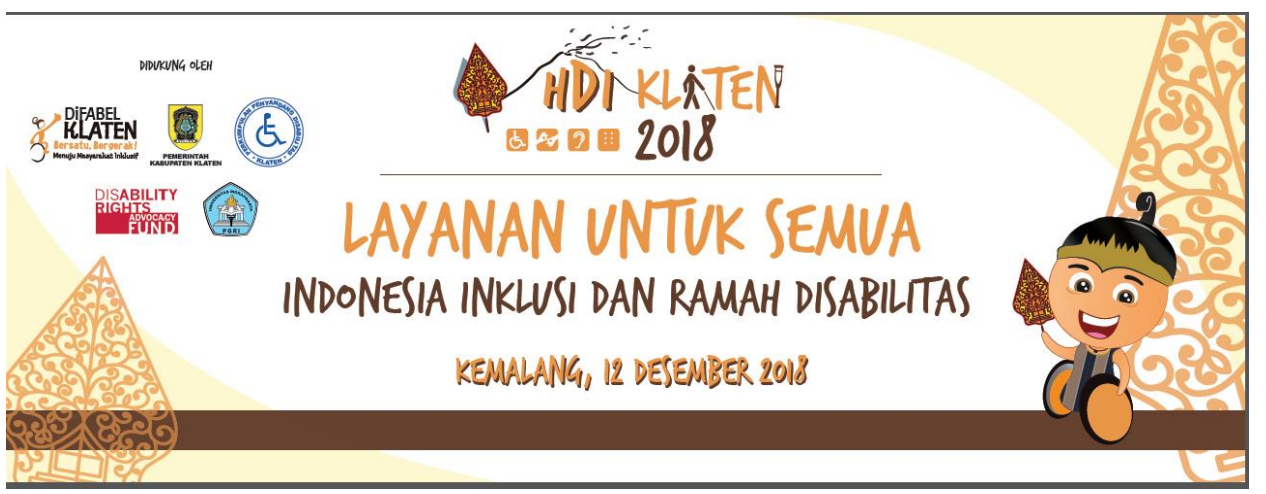

Gambar 2 Salah satu backdrop pada Acara HDI Klaten 2018 di Kemalang, yang telah menggunakan konsistensi logo dan maskot untuk materi kampanyenya

Sumber: Dokumen Mitra, 2018

Belum digunakannya bentuk kampanye yang terfokus hanya dengan menggunakan warna yang senada. Apalagi ada acara Hari Disabilitas Internasional yang diperingati setiap 3 Desember konsistensi desain penting untuk sebuah brand. Belum ada perencanaan dan ketetapan bagaiamana bentuk visual sebagai branding yang akan digunakan dalam acara tersebut membuatnya tidak konsisten.

Dengan melihat permasalahan yang ada, solusi yang akan diberikan dari kegiatan perancangan ini kami membuat perancangan kampanye, agar merek untuk advokasi kelompok difabel di Klaten tetap terjaga sesuai dengan isu yang dibawa dalam Hari Disabilitas Internasional yang jatuh pada tanggal 1 bulan Desember tahun 2019.

Menurut Rochaety and Tresnati (35) brand awareness merupakan kemampuan seseorang pelanggan untuk mengingat suatu merek tertentu atau iklan tertentu secara spontan atau setelah dirancang dengan kata-kata kunci. Kesadaran ini digunakan sebagai salah satu indikator efektivitas pemasaran. Definisi-definisi para ahli mengenai brand awareness dapat ditarik simpulan bahwa brand awareness merupakan tujuan umum komunikasi pemasaran, adanya brand awareness yang tinggi diharapkan kapanpun kebutuhan kategori muncul, brand tersebut akan dimunculkan kembali dari ingatan yang selanjutnya dijadikan pertimbangan berbagai alternatif dalam pengambilan keputusan. Aplikasi brand awarneness tidak lepas dari medianya. Media merupakan alat yang digunakan komunikator dan komunikan dalam 
melakukan proses komunikasi. Efisiensi penggunaan media dilihat dari sejauh mana media tersebut dapat menjangkau sasaran dengan tepat, (Morrisan dalam Winarto et al.). Brand awareness menunjukkan pengetahuan konsumen terhadap eksistensi suatu brand.

1. Rochaety and Tresnati (35) menambahkan peran brand awareness dalam ekuitas brand (nilai brand) tergantung pada tingkat pencapaian kesadaran dalam benak konsumen. Brand awareness dapat dibangun dan diperbaiki melalui cara-cara berikut:

2. Pesan yang disampaikan oleh suatu brand harus mudah diingat oleh konsumen.

3. Pesan yang disampaikan harus berbeda dengan produk lainnya serta harus ada hubungan antara brand dengan kategori produknya.

4. Memakai slogan maupun jingle lagu yang menarik sehingga membantu konsumen mengingat brand.

5. Jika suatu brand memiliki simbol, hendaknya simbol tersebut dapat dihubungkan dengan brandnya.

6. Perluasan nama brand dapat dipakai agar brand semakin diingat konsumen.

7. Brand awareness dapat dperkuat dengan memakai suatu isyarat yang sesuai dengan kategori produk, brand, maupun keduanya. Melakukan pengulangan untuk meningkatkan pengingatan, karena membentuk ingatan adalah lebih sulit dibanding membentuk pengenalan.

Target dari kegiatan pengabdian masyarakat yang berbentuk produk desain ini berupa perancangan kampanye adalah memberikan wawasan, pengetahuan serta produk siap pakai kepada organisasi difabel di Klaten guna mendukung advokasi yang dilakukan kelompokkelompok difabel di Klaten. Berdasarkan hal tersebut maka bentuk kegiatan pengabdian masyarakat yang akan diusulkan adalah sebagai berikut:

1. Kegiatan perancangan ini ditujukan kepada kelompok difabel di Klaten, yang akhirnya menjadi brand baru berupa Difabel Klaten.

2. Kegiatan perencanaan kampanye ini dibentuk bersama dengan organisasi-organisasi difabel di tingkat Kabupaten Klaten

3. Kegiatan ini bermanfaat untuk berjalannya advokasi yang dilakukan oleh kelompokkelompok difabel melalui komunikasi visual berupa logo dan penerapannya.

Hasil luaran yang diharapkan dari pelatihan dalam pengabdian masyarakat ini adalah membantu membangun brand yang sesuai dengan karakter kelompok difabel di tingkat kabupaten sebagai salah satu upaya untuk membantu advokasi secara visual melalui kampanye yang akan digunakan dalam Hari Disabilitas Internasional tanggal 3 Desember 2019, namun diperingati oleh Difabel Klaten pada tanggal 1 Desember 2019.

Melalui membangun brand awareness, metode pelaksanaan dalam pengabdian masyarakat ini dengan cara observasi yaitu merumuskan bersama dengan organisasiorganisasi difabel di Klaten berupa:

1. Brainstroming ide dan diskusi untuk perancangan kampanye

2. Penentuan isu-isu strategis yang akan dibawa dalam Hari Disabilitas Internasional di Klaten.

3. Menentukan obyek-obyek kunci visual untuk perluasan ide

4. Perancangan materi kampanye

5. Konsultasi untuk menentukan keseusuaian bentuk kampanye visual

6. Menyerahkan hasil perancangan kepada kelompok difabel di Klaten

7. Kemudian kami memberikan kesediaan dalam "Perancangan Materi Kampanye Disabilitas untuk Kelompok Difabel di Klaten, Jawa Tengah". 


\section{Hasil dan Pembahasan}

Kegiatan pengabdian masyarakat yang dilakukan di CFD Klaten ini merupakan usaha untuk membantu membentuk brand kelompok difabel Klaten yang akan mengkampanyekan kelompoknya menjadi kelompok difabel yang mandiri dan setara bagi sesamanya. Proses perancangan yang dilakukan oleh Universitas Indraprasta PGRI adalah menawarkan desain yang digunakan untuk membantu kelompok Difabel Klaten dalam membentuk image dirinya terhadap masyarakat Klaten.

Tahapan perancangan meliputi:

Me-review kegiatan HDI 2016 melalui foto sebagai pengetahuan awal mengenai acara tersebut:

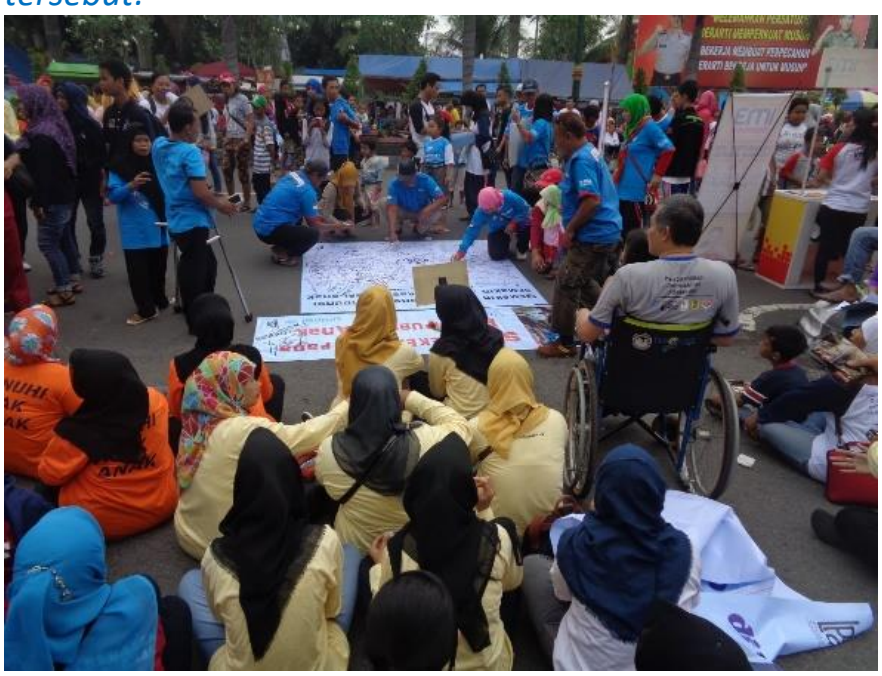

Gambar 3 Suasana kegiatan acara HDI 2016 di Klaten Sumber: Dokumen Mitra, 2016

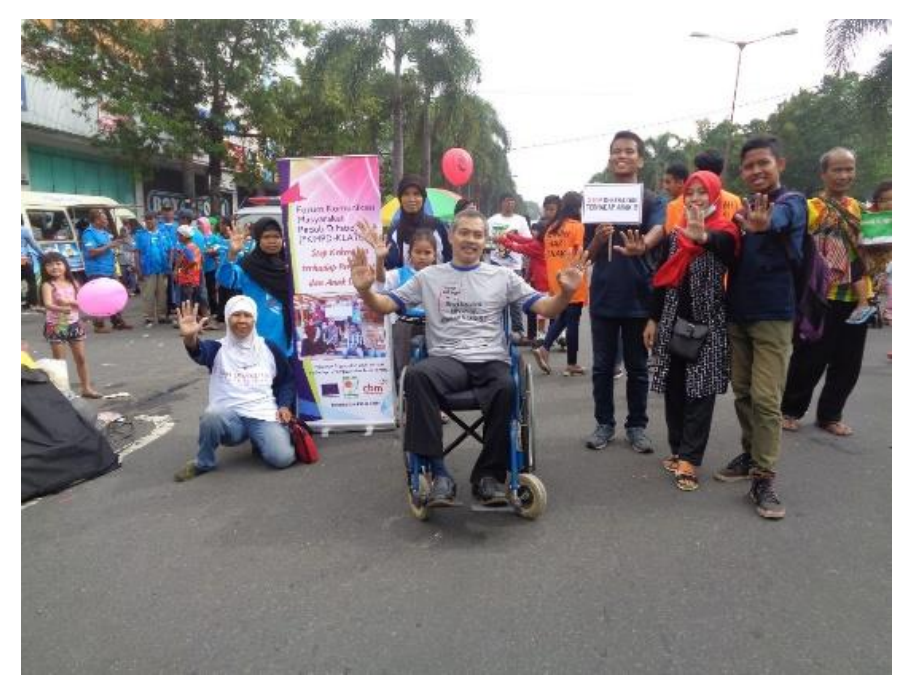

Gambar 4 Suasana kegiatan acara HDI 2016 di Klaten

Sumber: Dokumen mitra, 2016 


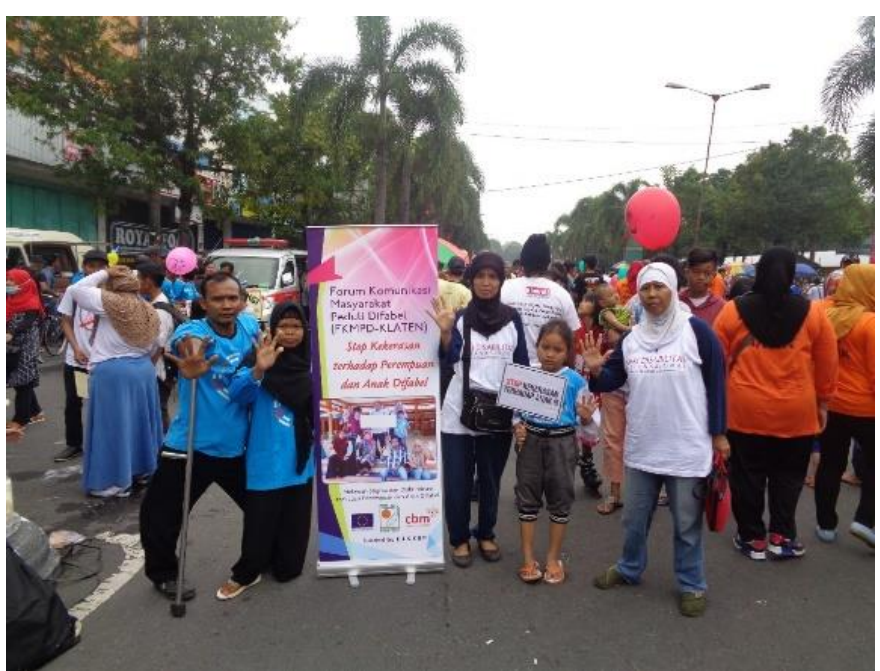

Gambar 5 Suasana kegiatan acara HDI 2016 di Klaten

Sumber: Dokumen Mitra, 2016

\section{Memahami brief}

Dalam merancang media kampanye acara Hari Disabilitas Internasional (HDI) Klaten 2019 diperlukan brief sebagai panduan agar tujuan dapat tercapai. Brief pada kegiatan ini yaitu:

Tabel 1 Difabel Klaten \& Universitas Indraprasta PGRI Jakarta for HDI 2019, 1 Desember 2019. Hari Disabilitas Internasional (HDI) di Car Free Day Klaten.

Diskusi kerjasama antara Difabel Klaten dengan Tim Abdimas DKV Unindra.

\begin{tabular}{|c|c|}
\hline Tema: & $\begin{array}{l}\text { "Menuju Masyarakat Inklusif, Tangguh, dan Berkesinambungan" | } \\
\text { Tema ini menyerap ide tema nasional yang akan diangkat pada HDI } \\
2019 .\end{array}$ \\
\hline $\begin{array}{l}\text { Isu krusial yang } \\
\text { diangkat: }\end{array}$ & Aksesbilitas dan Kebersamaan yang akan mewujudkan Inklusifitas. \\
\hline Target audiens: & $\begin{array}{l}\text { semua kalangan masyarakat, tidak terbatas pada usia, gender, dan } \\
\text { status sosial. Karena orang-orang di CFD sangat beragam. }\end{array}$ \\
\hline $\begin{array}{l}\text { Tanggal dan } \\
\text { tempat acara: }\end{array}$ & Minggu, 1 Desember 2019 di CFD Klaten \\
\hline Rangkaian acara: & $\begin{array}{l}\text { 1. Relawan Sampah } \\
\text { Berangkat dari } 3 \text { titik di lokasi paling luar CFD, menuju ke tengah di } \\
\text { wilayah RSPD Klaten. Kegiatannya berupa memungut sampah yang } \\
\text { berserakan. } \\
\text { 2. Demo Kursi Roda (berbentuk Atraksi, aksi show off menggunakan } \\
\text { kursi roda) } \\
\text { Dilakukan di sekitar RSPD. } \\
\text { 3. Kelas Bahasa Isyarat } \\
\text { Dilakukan di sekitar RSPD. } \\
\text { 4. Demo IT oleh teman-teman Netra } \\
\text { Dilakukan di sekitar RSPD } \\
\text { 5. Sensifitas Difabel } \\
\text { Dilakukan di sekitar RSPD }\end{array}$ \\
\hline
\end{tabular}




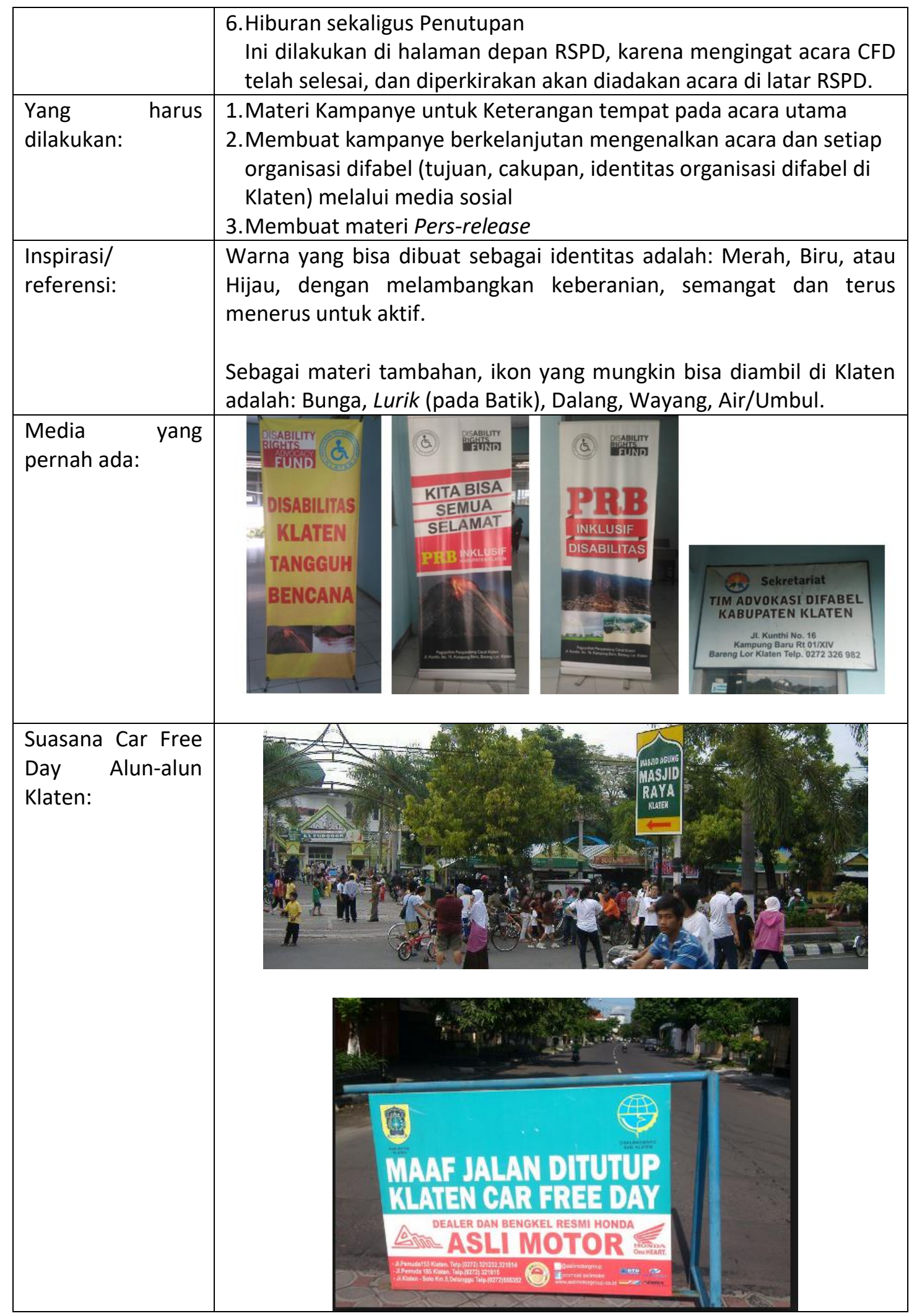

Sumber: Dokumen Pribadi 


\section{Brainstorming ide}

Langkah selanjutnya setelah me-review kegiatan HDI tahun lalu adalah brainstorming ide guna menemukan keyword, keyvisual, konsep visual (gaya visual, ilustrasi, warna, huruf), dan konsep verbal. Tahap ini dilakukan dengan berdiskusi sambil membuat mind mapping:

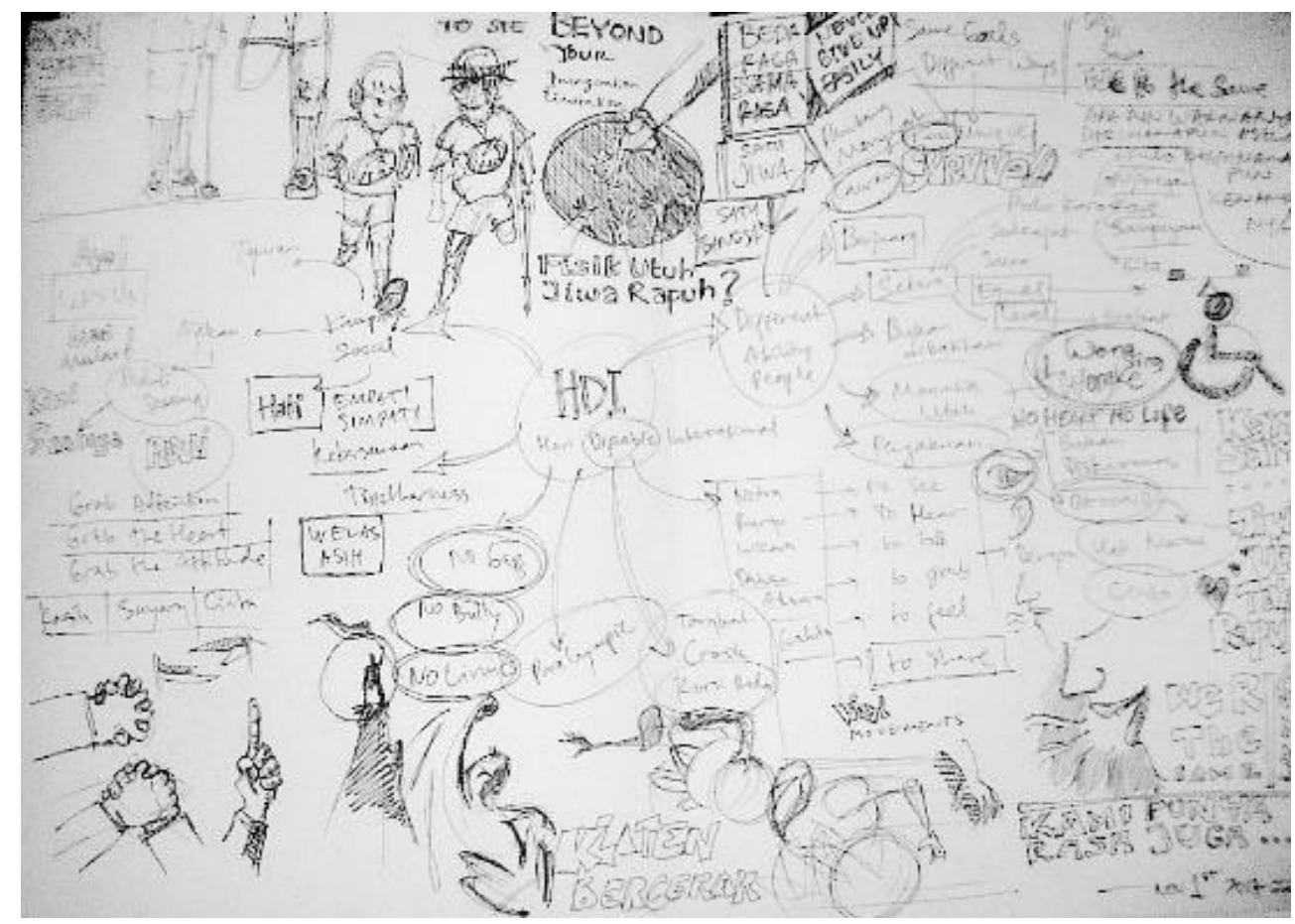

Gambar 6 Mindmapping

Sumber: Dokumen Pribadi, 2019

Mindmapping HDI dalam gambar 6 dibuat dengan tujuan untuk mencari kata kunci utama sebelum perancangan dilakukan, walau acara HDI Klaten dilaksanakan setiap tahunnya, tetap musti dicari keunggulan, keunikan dalam setiap acaranya, shingga didapat kata kunci sebagai landasan mengeksplorasi ide utama ke dalam media desainnya nanti.

\section{Membuat moodboard}

Keyword, keyvisual telah ditentukan setelah proses brainstorming. Langkah selanjutnya pembuatan moodboard. Dalam merancang desain media kampanye untuk acara HDI 2019 di Klaten, tim abdimas membuat moodboard yang terdiri dari warna-warna, foto dan ilustrasi gambar yang berkaitan dengan Klaten, profil target audiens, tempat acara, dan simbol difabel. Sumber gambarnya bisa didapat dari mitra maupun dokumentasi pribadi dan internet. Moodboard dapat dilihat pada gambar di bawah ini: 


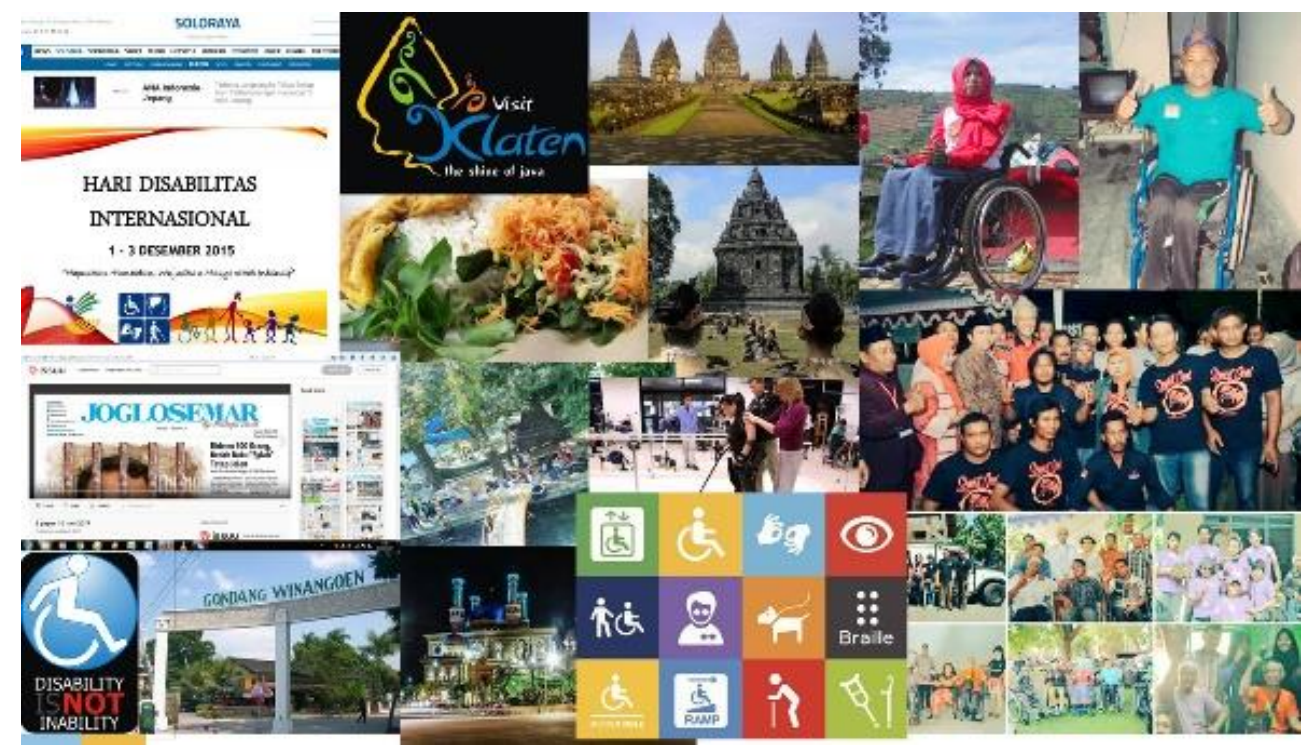

Gambar 7 Moodboard

Sumber: Dokumen pribadi, 2019

Dari hasil Moodboard pada gambar 7 ini, dapat disimpulkan menjadi skema warna dan jenis huruf, serta ikon-ikon tertentu yang menjadi landasan visual yang akan dikembangkan, dituangkan dan dibuat ke dalam media. Skema warna yang akan dipakai adalah bernuansa warna pastel dan lembut. Ikon-ikon yang akan dipakai berupa siluet-siluet manusia dengan gestur berdiri atau duduk dengan tangan terbuka untuk menampilkan sisi semnagat dan optmisme. Pilihan jenis huruf yang akan dipakai akan bernuansa tegas namun tetap memenuhi kaidah-kaidah keterbacaan dan kejelasan huruf.

\section{Membuat konsep perancangan kampanye HDI:}

Konsep yang ditawarkan dalam acara ini adalah berupa logo dan maskot untuk menggambarkan difabel Klaten yang sesuai dengan semangat Hari Disabilitas Internasional 2019. Perancangan kampanye HDI 2019 disepakati oleh tim abdimas dan Difabel Klaten akan menggunakan logo dan maskot sebagai konsep besar yang akan membawa ide untuk menunjukkan brand Difabel Klaten. Konsep perancangan materi kampanye HDI 2019 berdasar ide dari kata yang telah disepakati bersama berupa "Difabel Klaten Unggul!" dan menggunakan entitas "Difabel Klaten" dengan ilustrasi yang juga merupakan tongkat yang dipakai masyarakat Difabel untuk merepresentasikan bahwa HDI Klaten peduli terhadap disabilitas. llustasi tersebut sekaligus sebagai logo HDI 2019. Bentuk desain didominasi dengan typeface jelas dan kokoh, semakin memperkuat image dari tagline "Layanan Publik Untuk Semua!" yang artinya, Difabel harus bisa untuk bersatu, dan bergerak tanpa memandang bukan hanya dari mana organisasinya, apa jenis ke-difabel-annya, tapi bagaimana Layanan Publik setara peruntukannya kepada difabel atau regular bisa bergerak bersama untuk mencapai kesetaraan perlakuan. Bentuk simple dari tongkat merepresentasikan tentang kekuatan Difabel untuk terus maju. Tagline "Difabel Unggul Klaten Inklusi!" merupakan ajakan untuk Difabel Klaten menjadi semakin tangguh, dengan warna merah yang berarti semangat, Difabel Klaten mengajak masyarakat dalam berbagai hal dalam semangat kesetaraan. Memberikan pengaruh kepada masyarakat untuk dapat setara antara non-difabel dengan difabel. 


\section{Membuat sketsa}

Dengan berdasar pada konsep perancangan kemudian dibuat sketsa manual tangan beberapa alternatif:

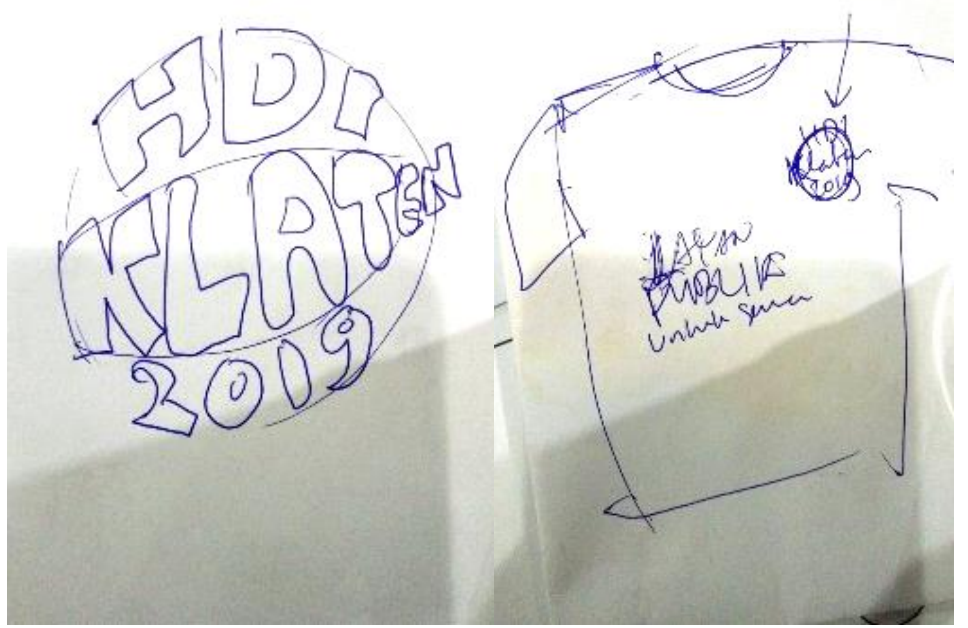

Gambar 8 Hasil sketsa manual

Sumber: Dokumen Pribadi, 2019

Pada gambar 8, sketsa logo acara dan copywriting dibuat dalam satu sisi depan kaos. Dengan mementingkan tagline pada posisi tengah area. Logo acara dibuat melingkar mencerminkan dunia global sebagai cerminan aktivitas kepedulian terhadap disabilitas yang sudah dilakukan di seluruh dunia.
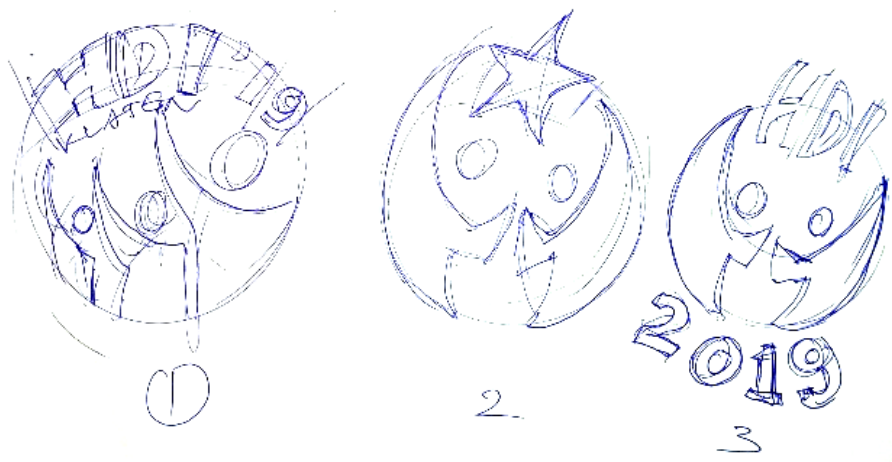

Gambar 9 Hasil sketsa manual

Sumber: Dokumen Pribadi, 2019

Pada Gambar 9 terdapat sketsa alternatif 3 logo acara yang mengacu pada satu ide besar yaitu masyarakat inklusi yang unggul dengan diturunkan menjadi beberapa tema desain. Sketsa pertama (dari kiri) menunjukkan 3 ikon manusia mewakili gerakan masyarakat difabel bersama masarakat umum saling bahu membahu menjunjung masyarakat inklusi, diiringi Brand tagline HDI'19 Klaten. Sketsa kedua dari kiri menunjukkan 2 ikon manusia dengan gestur semangat berjuang menuju masyarakat inklusi menuju 1 bintang yang mewakili cita-cita mulia, berdasar semangat masyarakat Indonesia yang penuh rasa kepedulian sosial. Sketsa ketiga dari kiri, dimunculkan dengan 2 ikon manusia sebagai cerminan masyarakat inklusi, dibubuhi dengan tulisan Brand tagline HDI 2019 Klaten, yang bermakna bahwa masyarakat bersatu dalam rangka memperingati acara HDI (Hari Disabilitas Internasional) 2019 di Klaten. 


\section{Mengerjakan desain computerized}

Dari hasil brainstorm yang telah dilakukan di atas, dibuatlah 3 sketsa logo yang dipilih kemudian dibuat computerized design-nya.

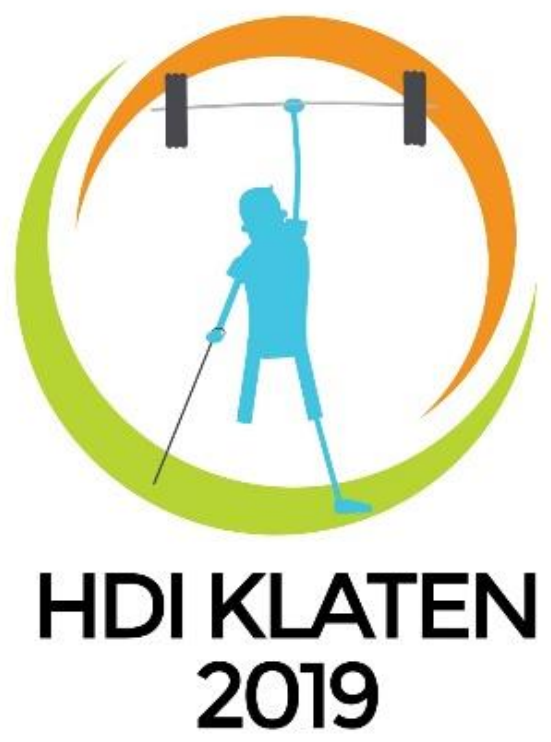

Gambar 10 Alternatif desain logo yang ditawarkan kepada mitra Sumber: Dokumen Pribadi, 2019

Ikon mnausia berwarna biru mengangkat halter, dengan kondisi kaki satu dan memakai tongkat, dibubuhi 2 garis lingkaran berwarna jingggga dan hijau, mempunyai makna bahwa masyarakat difabel tetap bisa melakukan aktivitas mereka walau dengan keterbatasannya mereka tetap semangat. Dua garis kurva melengkung adalah simbol kekuatan dan optimism yang digaungkan kepada dunia untuk mengakui bahwa mereka adalah individu yang berhak atas penghidupan yang layak setara dengan yang lain.

Merancang alternatif desain dan menunjukkannya kepada mitra untuk dipilih. Salah satu media kampanye HDI 2019 ini adalah kaos, karena kaos akan menjadi media sentral yang akan digunakan untuk acuan kampanye HDI Klaten 2019, maka 2 desain alternatif logo beserta tagline diaplikasikan pada kaos sebagai berikut:

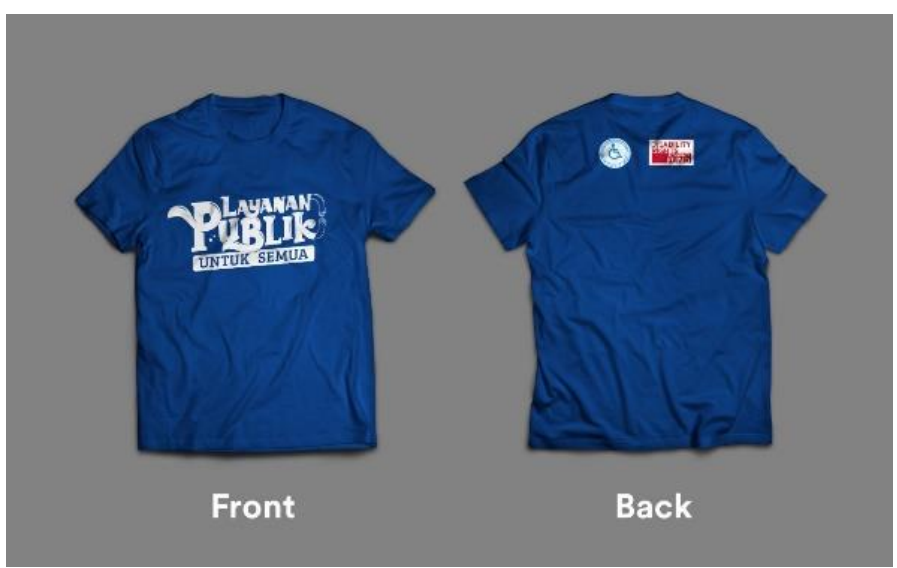

Gambar 11 Alternatif 1 desain kaos

Sumber: Dokumen Pribadi, 2019 


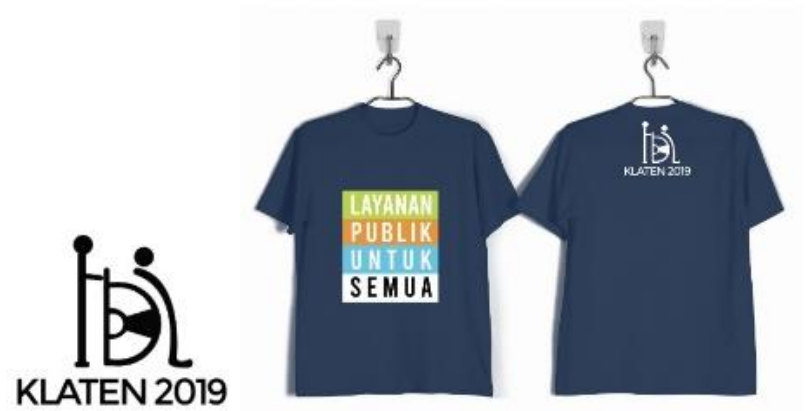

Gambar 12 Alternatif 2 desain kaos

Sumber: Dokumen Pribadi, 2019

Pada gambar 11 dan 12, terdapat tampilan kaos dengan hasil desain alternatif yang menerapkan tagline "Layanan Publik Untuk Semua". Kaos berwarna biru gelap sengaja dipakai agar citra warna lembut dan pastel pada tagline tetap bisa secara kontars terbaca jelas.
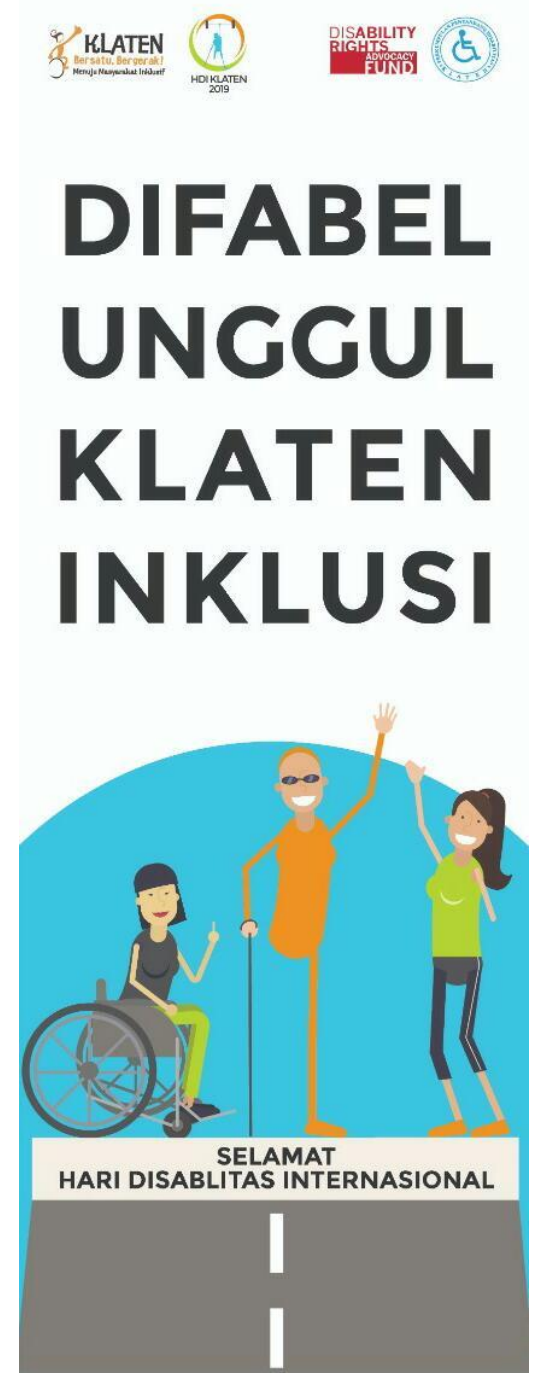

Gambar 13 Desain X.Banner

Sumber: Dokumen Pribadi, 2019 
Pada gambar 13 banner didesain dengan gaya flat design, dengan tujuan untuk memberikan gambaran yang sederhana dan mudah dimengerti dalam waktu singkat. Ikon 3 masyarakat difabel diwakili dengan gambar orang di atas kursi roda, orang dengan kaki satu dan tongkatnya, serta orang dengan tangan satu. Walau difabel itu beragam dan banyak lapisannya, 3 ikon ini dibuat hanya untuk membentuk konteks dalam masyarakat umum tentang semangat yang dibawa oleh mereka. Ekspresi/ mimik wajah digambarkan dengan ceria dan gestur yang semangat tanpa beban, ingin menularkan optimisme dan semangat dalam beraktivitas bagi sesama masyarakat difabel. Semangat yang sama tentang kepedulian sesama manusia juga disiratkan dengan warna-warna lembut bagi masyarakat umum agar mereka sadar tentang hal ini.

Desain yang terpilih kemudian akan dibuat juga aplikasinya pada media sosial dan media kampanye pada acara berlangsung. Setelah berdiskusi panjang mitra dan tim abdimas untuk membantu kampanye sebagai pembangun branding pada Hari Disabilitas Internasional Kabupaten Klaten 2019. Hasil perancangan kampanye oleh tim abdimas digunakan pada acara HDI 2019 oleh Difabel Klaten. Desain media kampanye HDI 2019 di Klaten dipakai pada akun media sosial, kaos, dan X-Banner Difabel Klaten dan juga dipakai pada saat acara berlangsung seperti gambar di bawah ini:

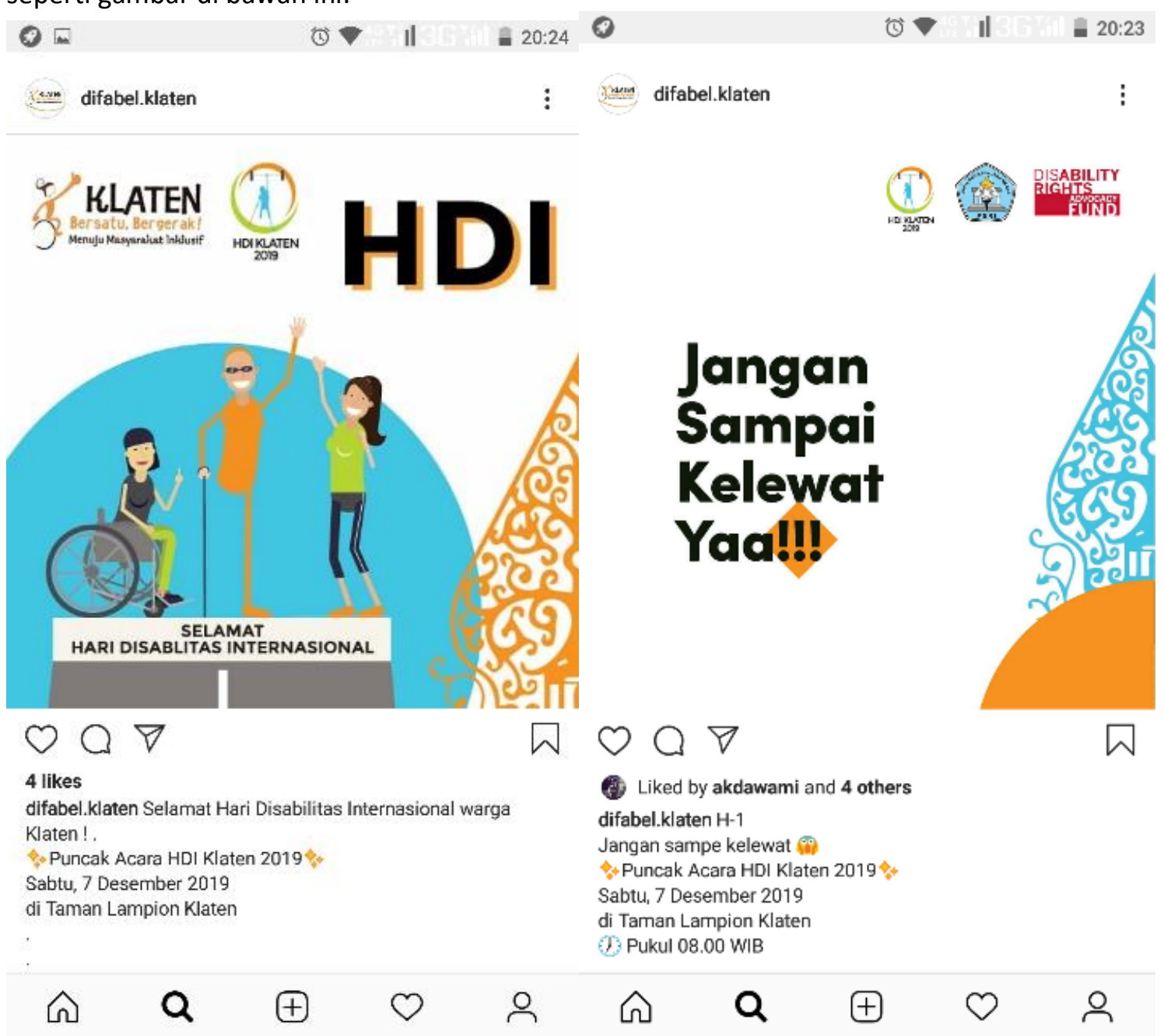

Gambar 14 Banner elektronik informasi HDI 2019 pada Instagram

Sumber: Instagram Difabel Klaten, 2019 
Pada gambar 14. Tampilan pada media sosial Instagram mulai terlihat konsisten dari segi warna dan bentulnya. Saat ini fenomena media sosial yang sedang terjadi di Indonesia yaitu pemanfaatan media sosial untuk berkampanye mempromosikan diri ataupun dengan tujuan membangun citra positif. Keberadaan media sosial memungkinkan sosialisasi atau kampanye lebih tepat sasaran, tetapi dengan biaya relatif murah.

Salah satu hal yang paling penting dari menggunakan kampanye digital, terutama dengan penggunaan media sosial sebagai alat untuk berkampanye pembangunan branding pada Hari Disabilitas Internasional Kabupaten Klaten 2019. Social media campaign memiliki kemampuan untuk menarik perhatian dan minat dari target audiens terhadap produk atau layanan. Hal ini semakin memberikan pembuktian bahwa media sosial adalah alat yang baik sebagai media kampanye dan promosi.

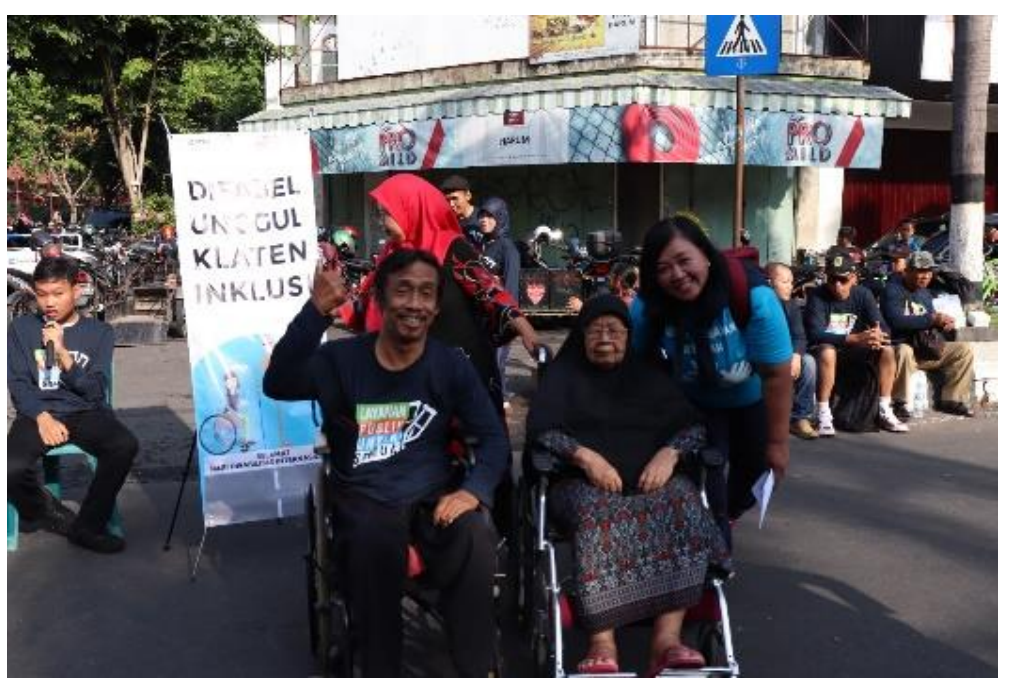

Gambar 15 Kaos dan x-banner informasi pada acara CFD

Sumber: Dokumen Pribadi, 2019

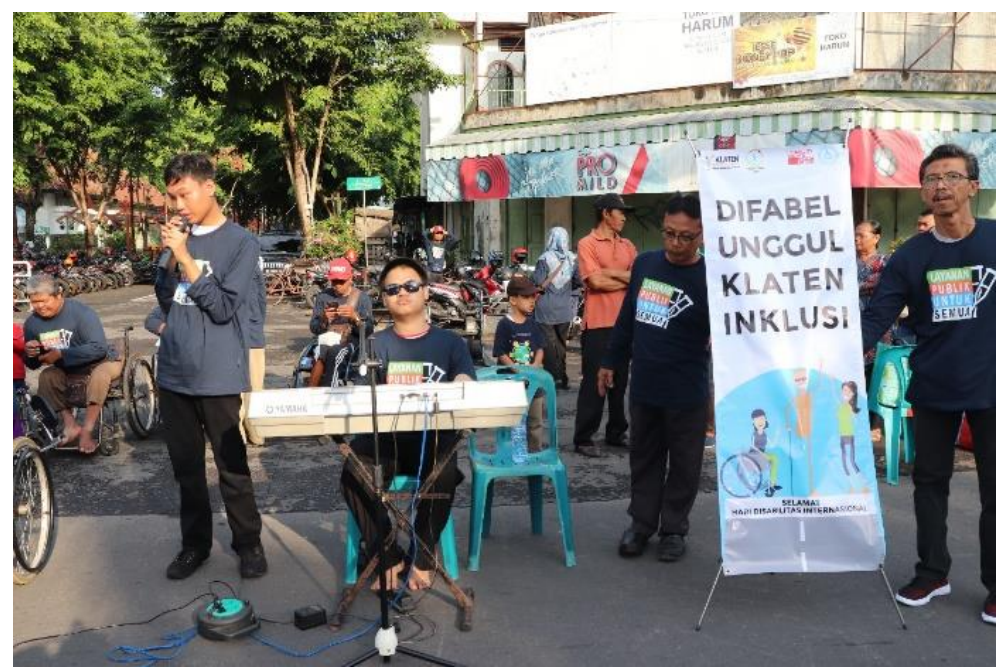

Gambar 16 Aplikasi logo pada desain kaos dan x-banner informasi HDI 2019 pada acara CFD Sumber: Dokumen Pribadi, 2019 


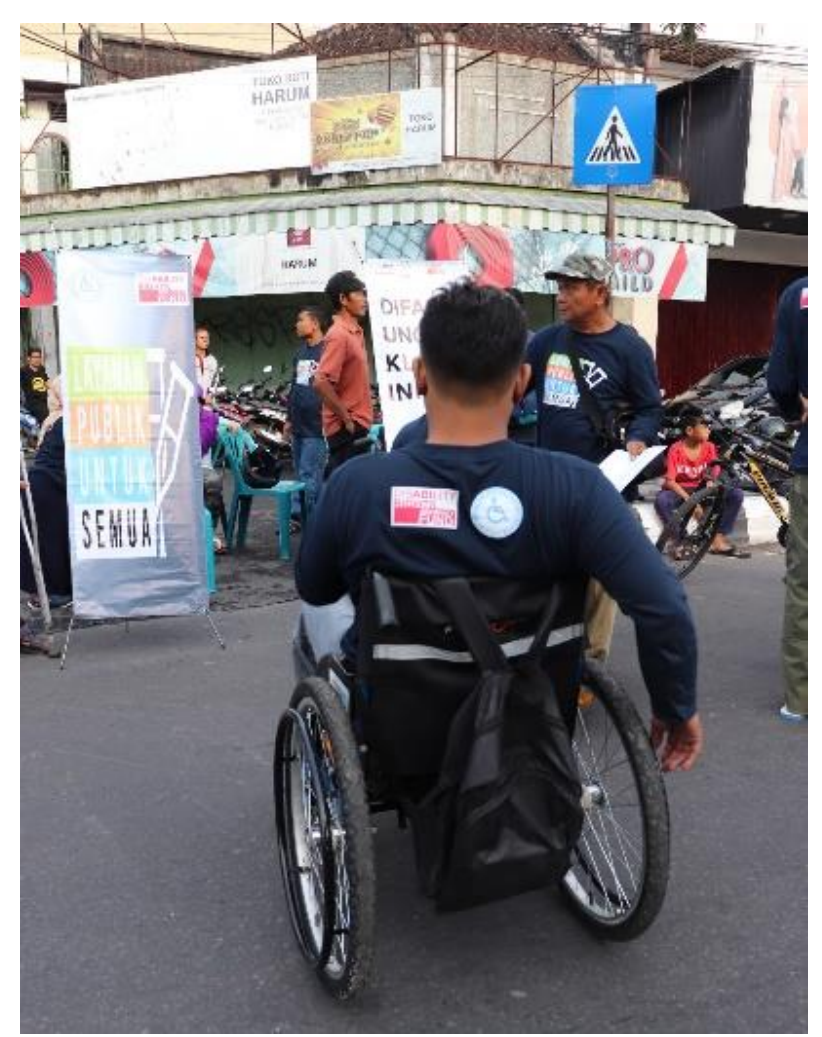

Gambar 17 Desain belakang kaos dan x-banner informasi pada acara CFD Sumber: Dokumen Pribadi, 2019

\section{Simpulan}

Berdasarkan pelaksanaan pengabdian masyarakat di acara Hari Disabilitas Internasional (HDI) tahun 2019, Forum Komunikasi Masyarakat Peduli Difabel (FKMPD) dan Persatuan Penyandang Disabilitas Klaten (PPDK) di Klaten, masih memerlukan dukungan dalam hal komunikasi visual dalam desain kampanye tentang kesetaraan mereka pada acara-acara yang lain. Perancangan pada acara HDI ini merupakan awal untuk membentuk persepsi target pendengar dan masyarakat secara umum dalam melihat difabel sebagai sebuah subyek yang sama dengan non-difabel lain. Perjuangan untuk mencapai kesetaraan juga harus didampingi dengan pembentukan citra yang positif oleh orang-orang yang peduli dengan difabel.

Pengabdian masyarakat berupa desain branding acara HDI merupakan bagian dari usaha mempertahankan eksistensi masyarakat disabilitas dan membangun kesadaran kepada masyarakat luas melalui pendekatan citra visual yang tertuang pada desain logo, maskot, media promosi, merchandise, dan sebagainya. Di sini peran tim pengabdian masyarakat menuangkan idenya ke dalam konsep desain dengan pendekatan karakter dan warna pastel dan lembut sebagai strategi pendekatan humanis. Walau belum sempurna, tetapi usaha untuk menemukan bentuk komunikasi yang tepat, khususnya dari sisi desain komunikasi visual cukup menjadi pertimbangan utama, karena akan direspon oleh laisan masyarakat yang berbedabeda. Untuk itu studi lebih lanjut tentang respon publik, atau evaluasi terhadap acara pada setiap tahunnya disarankan utnuk tetap ditinjau kembali.

Kesadaran brand HDI Klaten dalam hal ini kepada masyarakat tentang pentingnya masyarakat inklusi dirasa musti terus secara konsisten digaungkan. Hari Disabilitas Internasional (HDI) merupakan waktu yang tepat untuk dapat menyuarakan tema kesetaraan, 
agar komunikasi visual dapat dijalankan dengan baik oleh Difabel Klaten. Perancangan ini merupakan usaha Difabel Klaten untuk menyuarakan advokasi mereka melalui HDI. Terdapat banyak kekurangan, namun dengan dimulainya perancangan ini, terdapat kesadaran kelompok-kelompok difabel itu sendiri untuk membentuk brand mereka secara terstruktur. Masyarakat umum memang musti selalu dibangunkan kesadarannya agar mereka mengerti bahwa masyarakat difabel mempunyai tanggungjawab yang sama dalam bidangnya masing. Edukasi semacam ini akan secara konsisten dikumandangkan terus menerus minimal dimulia dari lingkungan komunitas terkecil sampai ke kancah internasional.

\section{Daftar Pustaka}

Fauziah, Ekky Ulfah et al. "Personal Branding of Hana Madness as an Mental Disability Doodle Artist." JCommsci-Journal Of Media and Communication Science, vol. 1, no. 3, 2019, pp. 132-145, doi:https://doi.org/10.29303/jcommsci.v1i3.52.

Foster, Bob. "Pengaruh Program Kewirausahaan Sosial Terhadap Kepercayaan Merek. Studi Kasus Komunitas Disabilitas Bandung, Indonesia." Jurnal Computech \& Bisnis, vol. 12, no. $\quad 1, \quad 2018, \quad$ pp. 101-110, http://www.jurnal.stmikmi.ac.id/index.php/jcb/article/view/174.

Indrawan, Cathleen Andrea et al. "Perancangan Kampanye Sosial Tentang Penggunaan Lajur Bersepeda Di Kota Surabaya." Jurnal DKV Adiwarna, vol. 1, no. 2, 2013, p. 13, http://publication.petra.ac.id/index.php/dkv/article/view/551.

Pramudyanto, Alexander Beny et al. "Pkm Di Komunitas Disabilitas Tuli Alumni Dena Upakara Dan Don Bosco Untuk Pengembangan Pemasaran Digital." IKRA-ITH ABDIMAS, vol. 2, no. 3, 2019, pp. 123-132, https://journals.upi-yai.ac.id/index.php/IKRAITHABDIMAS/article/view/598.

Probosiwi, Ratih. "Keterlibatan Penyandang Disabilitas Dalam Penanggulangan Bencana." Jurnal Penanggulangan Bencana, vol. 4, no. 2, 2013, pp. 5-12.

Rizky, Ulfah Fatmala. "Identifikasi Kebutuhan Siswa Penyandang Disabilitas Pasca Sekolah Menengah Atas." IJDS: Indonesian Journal of Disability Studies, vol. 1, no. 1, 2014, pp. 52-59, https://ijds.ub.ac.id/index.php/ijds/article/view/10.

Rochaety, Eti and Ratih Tresnati. Kamus Istilah Ekonomi. Bumi Aksara, 2005.

Rodiah, Mia Maisyatur. "Pemberdayaan Kelompok Disabilitas Melalui Kegiatan Ketrampilan Handicraft Dan Woodwork Di Yayasan Wisma Cheshire Jakarta Selatan." Fakultas IImu Dakwah dan Ilmu Komunikasi, vol. Sarjana, Skripsi, Universitas Islam Negeri Jakarta, 2014.

Untarni, Farahdini Amalia and Yanuar Rahman. "Perancangan Kampanye Sosial Meningkatkan Minat Baca Anak Melalui Bapusipda Di Kota Bandung." Desain Komunikasi Visual, Manajemen Desain Dan Periklanan (Demandia), vol. 1, no. 2, 2016, pp. 134-145, doi:https://doi.org/10.25124/demandia.v1i02.277. 
Wheeler, Alina. Designing Brand Identity Branding Is a Disciplined Process Used to Build Awareness and Extend Customer. John Wiley \& Sons, Inc, 2009.

Winarto, Bagus Adi et al. "Perancangan Kampanye Sosial Tujuh Zona Merah Pkl Kota Bandung." eProceedings of Art \& Design, vol. 2, no. 3, 2015, pp. 998-1006, https://openlibrary.telkomuniversity.ac.id/pustaka/files/104044/jurnal eproc/peranca ngan-kampanye-sosialtujuh-zona-merah-pkl-kota-bandung.pdf. 